American Journal of Infectious Diseases 7 (1): 16-19, 2011

ISSN 1553-6203

(C) 2011 Science Publications

\title{
Seroprevalence of Rubella Virus in Women with Spontaneous Abortion
}

\author{
${ }^{1}$ Abdolreza Sotoodeh Jahromi, ${ }^{1}$ Akbar Kazemi, ${ }^{2}$ Gita Manshoori, \\ ${ }^{3}$ Abdolhossien Madani, ${ }^{4}$ Seyed-Hamid Moosavy and ${ }^{3}$ Bita Seddigh \\ ${ }^{1}$ Department of Immunology, \\ Jahrom University of Medical Sciences, Jahrom, Iran \\ ${ }^{2}$ Department of Infectious Diseases, \\ Tehran University of Medical Sciences, Tehran, Iran \\ ${ }^{3}$ Department of Epidemiology, Health Promotion Research Center, \\ Hormozgan University of Medical Sciences, Banddar Abbas, Iran \\ ${ }^{4}$ Department of Internal Medicine, Hormozgan University of Medical Sciences, \\ Banddar Abbas, Iran
}

\begin{abstract}
Problem statement: Recurrent abortion is a difficult medical problem happening in about $1-2 \%$ of fertile women. Rubella is of high public health importance owing to teratogenic effects that can lead to fetal death, miscarriage, stillbirth, or infants during the first 16 weeks of gestation. As there were not data about role this virus in abortion in this area of IRAN, this study was conducted to assess the seroprevalence of Rubella virus in women with spontaneous abortion in comparison with healthy women (without history of abortion) in South of IRAN in order to establish basic knowledge for future pregnancy care in this area of IRAN. Approach: Present survey basically was carried out in Shariatee Hospital of Hormozgan University of medical sciences, Bandarabbas, Hormozgan province, located in border of Persian Gulf-2005. A number of 220 women with definite diagnosis of previous abortion and 200 matched women with normal full term delivery and without history of miscarriage as controls were studied as case and control groups. All obtained sera from the case and the control groups were then tested using ELISA method for determine of rubella virus antibodies. Data was analyzed, using SPSS software (chi square and t-test). Results: There were significant differences in seroprevalence of anti-rubella IgG and IgM in the case group than in the control group. Conclusion: According to the results of our research, rubella virus is presented as an etiologic factor for spontaneous abortion in this area of IRAN.
\end{abstract}

Key words: Rubella virus, spontaneous abortion, etiologic factor, Enzyme-Linked Immunosorbant Assay (ELISA), full-term deliveries, control groups, blood samples, significant differences, Congenital Rubella Syndrome (CRS)

\section{INTRODUCTION}

Background: Rubella (German measles) is a viral disease that usually presents as a mild febrile rash illness with adenopathia in adults and children; $20-50 \%$ of infected persons are asymptomatic. The infection is acquired through direct contact with nasopharyngeal secretions containing the virus or through droplet spread of nasopharyngeal secretions. Laboratory diagnosis of rubella is required, since clinical diagnosis is often inaccurate. According to the case definitions proposed by the European Commission, laboratory confirmation should be based on the detection of a significant rise in rubella immunoglobulin $\mathrm{G}$ ( $\mathrm{IgG}$ ) antibody titers in the serum between acute and convalescent phase or on the isolation of rubella virus from nasal, blood, throat, urine, or cerebrospinal fluid specimens, on the detection of rubella virus nucleic acid by reverse transcription PCR (RT-PCR) in one of these clinical specimens, or in an outbreak situation on the detection of rubella-specific immunoglobulin M (IgM) antibody in serum or saliva. An epidemiologically confirmed rubella case is defined as a patient with a febrile generalized rash illness of acute onset and an epidemiological link to a laboratory-confirmed case (Tipples and Hiebert, 2011).

Rubella is generally a mild rush fever disease when acquired in childhood, but when infection occurs during

Corresponding Author: Bita Seddigh, Department of Epidemiology, Health Promotion Research Center,

Hormozgan University of Medical Sciences, Banddar Abbas, Iran 
the first months of gestation, leading to fetal death, miscarriage, stillbirth, or infants with a pattern of birth defects, known as Congenital Rubella Syndrome (CRS) (Canepa et al., 2009).

The objectives of this study were to assess the seroprevalence of Rubella virus in women with spontaneous abortion in comparison with healthy women (without history of abortion) in South of IRAN in order to establish basic knowledge for future pregnancy care in this area of Iran.

\section{MATERIALS AND METHODS}

This cross sectional and descriptive study was conducted at in the delivery population of University Hospital (Hormozgan Province, Iran) between July 2004-Feb. 2005, to investigate whether seroprevalence of rubella virus in two groups of women with spontaneous abortion and without history of abortion to determine a relationship between the roles of rubella virus infection in spontaneous abortion as well as factors which might have an influence in the pathogenesis of this infection.

Cases were 220 women who were identified with spontaneous abortion by gynecologist during the study period and control group consisted of 200 asymptomatic women with no history of abortion and with successful full term delivery who were referred to Hormozgan University Hospital.

All subjects gave written consent for obtaining their blood samples according to research purposes.

Blood samples were taken from all women in both groups. A structured interview using a standard maternal questionnaire was administered by trained interviewers with the women at their first visit. Questions were asked about the following: age, parity, gynecologic and medical history of abortion, residence and socioeconomic status.

Serologic studies: In order to determine the rubella serology, 5 cc venous blood samples were taken and isolated sera stored at $-70^{\circ} \mathrm{C}$ until $\mathrm{IgG}$ antibodies for rubella were qualified by Enzyme-Linked Immunosorbant Assay (ELISA) using the Trinity Biotech Rubella ELISA kits (Trinity Biotech, Jamestown, N.Y., USA). All sera with IgG titers equal to or below $6.50 \mathrm{IU} \mathrm{ml}^{-1}$ were regarded as seronegative, titers between 6.51-8.10 $\mathrm{IU} \mathrm{mL}^{-1}$ were regarded as equivocal and titers between $8.11 \mathrm{IU} \mathrm{mL}^{-1}$ and above were regarded as seropositive as indicated in the kit prospectus. Sera with titers in the equivocal range were retested once and the sera that were still in the equivocal range were presented as seronegative.

Rubella virus-specific IgM and IgG were detected by indirect Enzyme-Linked Immunosorbant Assay (ELISA) by commercial specific kits Biokit,S.A.Liscad Amunt. Barcelona-Spain).

Data analysis: For assessment of risk factors for Chlamydia trachoma is infection (exposure), characteristics of case patients and control subjects were examined using a two-sample Student $\mathrm{t}$ test. Cross-tabulation and chi-square or Fisher exacts tests were used to examine the relationship between variables using a 95\% confidence interval as a measure of association.

All data analyses were performed using SAS 8 Statistical Software (SAS Institute, Inc., Cary, NC).

\section{RESULTS}

The mean age of participants was $25.6 \pm 7.6$ and $25.3 \pm 6.5$ years in the pregnant women with abortion and with full term delivery, respectively. The mean gestational age was 8 weeks and the mean parity was 2.52 children in abortion group. The mean gestational age was $37 \pm 2$ weeks and the mean parity was 2.2 children in full term group. There was no significant difference between age and parity in two groups $(\mathrm{p}=$ 0.650) (Table 1).

There were significant differences in seroprevalence of anti-rubella $\operatorname{IgG}$ and $\operatorname{IgM}$ in the case group than in the control group (Table 2).

There was not find any statistically significant association between seroprevalence of rubella (IgG and $\operatorname{IgM}$ ) and residence (city or village) and also between seroprevalence of rubella (IgG and $\operatorname{IgM}$ ) and parity neither in patients nor in healthy women.

Table 1: Baseline data of case and control groups*

\begin{tabular}{llll}
\hline Variables & Cases $\mathrm{n}=250$ & Controls $\mathrm{n}=200$ & $\mathrm{p}$-value \\
\hline $\begin{array}{l}\text { Age (year) } \\
\text { Residence }\end{array}$ & $24.6 \pm 7.4$ & $25.6 \pm 7.20$ & 0.650 \\
city & $186(84.54 \%)$ & $154(77.0 \%)$ & 0.040 \\
Village & $34(15.45 \%)$ & $46(23.0 \%)$ & 0.040 \\
\hline
\end{tabular}

*: Data are presented as $\mathrm{n}(\%)$ or mean \pm standard deviation

Table 2: Frequency of anti-rubella IgG and $\operatorname{IgM}$ in case and control groups*

\begin{tabular}{llll}
\hline Variables & Cases $\mathrm{n}=250$ & Controls $\mathrm{n}=200$ & $\mathrm{p}$-value \\
\hline Anti-rubella IgG & $228(91.20 \%)$ & $164(82.0 \%)$ & 0.031 \\
Anti-rubella IgM & $34(10.80 \%)$ & $11(5.50 \%)$ & 0.022 \\
\hline *. Data are presented as numbers and \%
\end{tabular}




\section{DISCUSSION}

According to significant difference between antirubella $\operatorname{IgG}$ in women with abortion $91.20 \%$ compared women with full-term deliveries $82.0 \%$ and anti-rubella IgM in women with abortion $10.80 \%$ compared women with full-term deliveries $5.50 \%$, rubella virus is an important causative agent for spontaneous abortion in this area of Iran.

A studies in the Baghdad, Iraq, the seroprevalence of rubella virus in women with abortion was $34.2 \%$ (Abdul-Karim et al., 2009) and in another study rubella was considered as an etiologic agent for abortion in Gaza strip, Palestine (Al-Hindi et al., 2010).

In another report from Leningrad County, Russia, the seroprevalence of rubella virus in women with abortion and in healthy women were 77.5 and $59.8 \%$ respectively (Odland et al., 2001). In another study in Nigeria, the seroprevalence of rubella virus in women with abortion and in healthy women were $86 \%$ and $77 \%$ respectively (Onyenekwe et al., 2000).

The frequency of anti-rubella antibodies resulted from these research are lower than our finding, but there is the same results from these studies and our study, which is:"rubella virus is an etiologic factor for spontaneous abortion ".

Previous studies about etiologic factors for abortion in this area of IRAN (Bandarabbas), infectious agents such as Listeria monocytogenes (Jamshidi et al., 2009), Toxoplasma gondii and Cytomegalovirus (Jahromi et al., 2010a) and also immunologic factor such as anticardiolipin antibody and antinuclear antibody and Anti B2-Glycoprotein I Antibodies (Jahromi et al., 2010b) and Chlamydia trachomatis (Jahromi et al., 2010c) were suggested as important causative agents for spontaneous abortion.

In some countries socio-economic and demographic factors (Alpu and Kurt, 2004), dengue virus (Alvarenga et al., 2009) and Women age and their parity (Adeleke and Adepoju, 2010) were suggested as cause of abortion.

\section{CONCLUSION}

According to the results of our research, rubella virus is presented as an etiologic factor for spontaneous abortion in this area of IRAN. Routine screening rubella is needed for pregnant women in Iran.

\section{ACKNOWLEDGMENT}

We thank the staffs of the Shariatee Hospital of Bandar Abbas who provided the sera and the staff at the
Microbiology department of Hormozgan University of Medical Sciences for their help in processing and testing the sera.

\section{REFERENCES}

Abdul-Karim, E.T., N. Abdul-Muhymen and M. AlSaadie, 2009. Chlamydia trachomatis and rubella antibodies in women with full-term deliveries and women with abortion in Baghdad. East Mediterr. Health J., 15: 1407-1411. PMID: 20218131

Adeleke, K.A. and A.A. Adepoju, 2010. Ordinal logistic regression model: An application to pregnancy outcomes. J. Math. Stat., 6: 279-285. DOI: $10.3844 /$ jmssp.2010.279.285

Al-Hindi, A., T. Al-Helou and Y. Al-Helou, 2010. Seroprevalence of toxoplasma gondii, cytomegalovirus, rubella virus and Chlamydia trachomatis among infertile women attending in vitro fertilization center, Gaza strip, Palestine. J. Egypt Soc. Parasitol., 40: 451-458. PMID: 21246952

Alpu, O. and G. Kurt, 2004. The effect of socioeconomic and demographic factors on contraceptive use and induced abortion in Turkey. Am. J. Applied Sci., 1: 332-337. DOI: 10.3844/ajassp.2004.332.337

Alvarenga, C.F., V.G. Silami, P. Brasil, M.E.H. Boechat and J. Coelho et al., 2009. Dengue during pregnancy: A study of thirteen cases. Am. J. Infect. Dis., $\quad$ 5: 288-293. 10.3844/ajidsp.2009.288.293

Canepa, P., L. Valle, E. Cristina, D. De Florentiis and V. Parodi et al., 2009. Role of congenital rubella reference laboratory: 21-months-surveillance in Liguria, Italy. J. Prev. Med. Hyg., 50: 221-226. PMID: 20812517

Jahromi, A.S., M.J. Makiani, M.R. Farjam, A. Madani and M. Amirian et al., 2010a. Cytomegalovirus immunity in pregnancy in South of Iran. Am. J. Infect. Dis., 6: 8-12. DOI: 10.3844/ajidsp.2010.8.12

Jahromi, A.S., M.R. Farjam, F. Mogharrab, A. Daryanavard and A. Madani et al., 2010b. Anti $\beta_{2^{-}}$ glycoprotein I antibodies in women with recurrent spontaneous abortion. Am. J. Biochem. Biotechnol., 6: 264-267. DOI: 10.3844/ajbbsp.2010.264.267

Jahromi, A.S., M.R. Farjam, F. Mogharrab, M. Amiryam and M.J. Makiani et al., 2010c. Chlamydia trachomatis in women with ful-term deliveries and women with abortion. Am. J. Infect. Dis., 6: 66-69. DOI: 10.3844/ajidsp.2010.66.69 
Jamshidi, M., A.S. Jahromi, P. Davoodian, M. Amirian and M. Zangeneh et al., 2009. Seropositivity for listeria monocytogenes in women with spontaneous abortion: A case-control study in Iran. Taiwan J. Obstet. Gynecol., 48: 46-48. PMID: 19346191

Odland, J.O., I.V. Sergejeva, M.D. Ivaneev, I.P. Jensen and B. Stray-Pedersen, 2001. Seropositivity of cytomegalovirus, parvovirus and rubella in pregnant women and recurrent aborters in Leningrad County, Russia. Acta Obstet. Gynecol. Scand., 80: 1025-1029. PMID: 11703200
Onyenekwe, C.C., T.A. Kehinde-Agbeyangi, U.S. Ofor and O.G. Arinola, 2000. Prevalence of rubella-IgG antibody in women of childbearing age in Lagos, Nigeria. West Afr. J. Med., 19: 23-26. PMID: 10821082

Tipples, G. and J. Hiebert, 2011. Detection of measles, mumps, and rubella viruses. Methods Mol. Biol., 665: 183-93. PMID: 21116802 